\title{
Phenotypic Characterization of Jhum Rice (Oryza sativa L.) Landraces Collected from Rangamati District in Bangladesh
}

\author{
M Z Islam ${ }^{1 *}$ M Khalequzzaman ${ }^{1}$, M A Siddique ${ }^{1}$, N Akter ${ }^{1}$, M S Ahmed ${ }^{1}$ \\ and M A Z Chowdhury ${ }^{2}$
}

\begin{abstract}
Genetic diversity of 30 Jhum rice landraces was studied under irrigated condition through Mahalanobis $\mathrm{D}^{2}$ statistic for agro-morphological characters. The landraces were grouped into five clusters. The intercluster distances were higher than intra-cluster distances indicating wider genetic diversity among the landraces of different clusters. The intra-cluster distances were lower in all the cases reflecting homogeneity of the genotypes within the clusters. The principal component analysis exposed that the first five components with vector values $>1$ contributed $81.14 \%$ of the total variations. The highest number (8) of landraces was observed in cluster IV and the lowest (4) in cluster II. The intra-cluster distance was maximum in cluster III (1.62) containing six landraces and minimum in cluster I (0.57) having six landraces. The highest inter cluster value was 23.44 (between cluster II and V) and the lowest was 7.29 (between cluster III and IV). The highest flag leaf length, leaf area index, filled grains per panicle were found in cluster $\mathrm{V}$ while the lowest culm diameter, short duration, low yielding genotypes were clubbed into cluster II. Dwarf stature and lower flag leaf length were recorded into cluster I whereas the highest plant height and panicle length were obtained from cluster IV. Based on canonical vector analysis, culm diameter, days to flowering, days to maturity and length-breadth ratio had maximum contribution towards genetic divergence. Selection of parents from the clusters II and V followed by hybridization would possibly result in desirable transgressive segregants. Finally, Jhum rice landraces need to be conserved in Genebank for future breeding programme.
\end{abstract}

Key words: Genetic diversity, Jhum rice landraces, agro-morphological characters

\section{INTRODUCTION}

Rice (Oryza sativa L.) is considered as a major cereal crop in Bangladesh since it is the main staple food for most Bangladeshi people. Rice production area in Bangladesh is about 11.4 million hectares (ha) of land in which 51.64 million tons of rice is produced (BBS, 2015). It constitutes over $91 \%$ of the food grain production in Bangladesh. About $76 \%$ of the total cropped land is covered by rice and more than $66 \%$ of the total agriculture labour force is employed in rice production, processing, marketing and distribution. It provides about $62 \%$ of the calorie and $46 \%$ of the protein in the average daily diet for the people of the country (HIES, 2010).
In Bangladesh, three major rice crops namely Aus, Aman and Boro constitute $100 \%$ of total rice production and grow in three overlapping seasons with large number of varieties that suit various agro-ecological and climatic nitches. The Aus season usually starts in March-April and the crop is harvested in July-August. Aus rices are of two cultural types specifically Broadcast Aus (B. Aus) and Transplanted Aus (T. Aus). B. Aus is direct seeded in dry land rainfed condition. Transplanted Aus is grown under partially irrigated or rainfed condition. Average yield of Aus is $2.00 \mathrm{t} / \mathrm{ha}$ in Bangladesh.

The Chittagong Hill Tract (CHT) has an area of $13,180 \mathrm{~km}$, making up approximately $10 \%$ of the total area of Bangladesh. Rangamati is the largest district of CHT. Its area is 6116.13

${ }^{1}$ Genetic Resources and Seed Division, BRRI, Gazipur and ${ }^{2}$ Member Director (Crops), BARC, Dhaka. *Corresponding author's E-mail: zahid.grs@gmail.com 
sq. $\mathrm{km}$ and 12 tribes live in Rangamati. The main job of the tribes is mostly crop, livestock, horticulture and forestry agriculture. In ancient days, the tribal people who lived in hilly areas used to practice shifting cultivation, which is locally called Jhum cultivation. It is a unique kind of agricultural practice on sloppy hills of the aboriginal people of $\mathrm{CHT}$ region. The method is also known as 'Slash and Burn' or 'Sweden' cultivation. Jhuming compromises cutting and burning of forest trees, clearing spaces and then sowing a variety of seeds. About 20,000 hectares of land are being brought under Jhum cultivation every year. The farmer usually grows low yielding local landraces. More than 300 local Jhum rice landraces have been collected from various locations in CHT, Bangladesh and conserved in Bangladesh Rice Research Institute (BRRI) Genebank (Source: BRRI Genebank accession book). This collection is an invaluable genetic resource that can be used for varietal improvement.

Genetic diversity in the available gene pool is the foundation or the raw material of all plant improvement programme. The availability of transgressive segregants in any breeding programme also depends on effective inclusion of parents. Several genetic diversity studies have been successfully utilized in different crop species based on quantitative and qualitative traits in order to select genetically distant parents for hybridization (Bedoya et al., 2017; Ahmed et al., 2016a; Islam et al., 2016; Malek et al., 2014; Khodadadi et al., 2014 ).

Bangladesh has abundant diversified rice landraces from time immemorial. More than 8,000 rice germplasm have been registered in BRRI Genebank (BRRI, 2016). Among them, about 1,500 Aus rice landraces also have been conserved in BRRI Genebank. But scant information is available on genetic divergence about hilly rice landraces especially in Rangamati district. Keeping this in view, the present study was focused to assess the genetic diversity of 30 Jhum rice landraces using Mahalanobis $\mathrm{D}^{2}$ statistics.

\section{MATERIALS AND METHODS}

\section{Collection of Jhum rice landraces}

A total of 30 Jhum rice landraces (Table 1) were collected from Rangamati districts of Bangladesh during 24-28 October, 2015 by Dr M Z Islam and colleagues, Bangladesh Rice Research Institute (BRRI) under Asian Food and Agriculture Cooperation initiative (AFACI) project. All rice landraces were grown under Jhum. Fresh seed stocks for each landrace were collected from fields and farmer's store. The collected landraces have been conserved at short term storage of the BRRI Genebank.

\section{Characterization of germplasm for agro- morphological traits}

The collected Jhum rice landraces were characterized for agro-morphological traits. These studies were conducted in RCB design with three replications at the experimental field of BRRI, Gazipur, during March to July (Aus season) 2016. Twenty-day-old seedlings from each entry were transplanted using single seedling per hill in $2.4 \mathrm{~m}^{2}$ plot. Row to row and plant to plant distances were maintained as $25 \mathrm{~cm}$ and $20 \mathrm{~cm}$, respectively. Fertilizers were applied @ 60:20:40:12 kg N, P, K and S per hectare. All the fertilizers except $\mathrm{N}$ were applied at final land preparation. Nitrogen was applied in three equal splits, at 15 days after transplanting (DAT), at 35 DAT and just before flowering. Intercultural operations and pest control measures were done as and when necessary.

Twenty-three qualitative traits namely blade pubescence, blade colour, leaf sheath: anthocyanin colour, basal leaf sheath colour, flag leaf angle, ligule colour, ligule shape, coller colour, auricle colour, culm:anthocianin colouration of nodes, culm angle, internode colour, culm strength, panicle type, panicle exertion, spikelet: awns in the spiklet, distribution of awing, awn colour, apiculus colour, stigma colour, lemma and palea colour, seed coat (bran) colour and leaf senescence were scored based on 'Descriptors for cultivated 
Table 1. Information on local name, place of collection, season and origin of the Jhum rice landraces.

\begin{tabular}{|c|c|c|c|c|}
\hline Name & Upazila & District & Season & Origin \\
\hline Kobrok-1 & Rangamati Sadar & Rangamati & Jhum & Bangladesh \\
\hline Vanguri Jhum & " & " & " & " \\
\hline Amey-1 & " & " & " & " \\
\hline Horinbinni & , & " & , & " \\
\hline Bairi & " & $"$ & , & " \\
\hline Lonkapara binni & " & " & " & " \\
\hline Turni & " & , & " & " \\
\hline Vanguri valo & , & $"$ & " & $"$ \\
\hline Bandornok binni & " & " & , & " \\
\hline Kamarang-1 & $"$ & $"$ & $"$ & $"$ \\
\hline Lokkhi binni & " & " & " & " \\
\hline Gonda & $"$ & " & " & " \\
\hline Kangbui & " & " & , & " \\
\hline Koborok-2 & " & " & , & " \\
\hline Galong & " & " & " & " \\
\hline Chorui & " & $"$ & " & " \\
\hline Pattiki & " & $"$ & " & $"$ \\
\hline Amey-2 & " & " & " & " \\
\hline Guri & " & " & $"$ & " \\
\hline Kamarang-2 & " & " & , & " \\
\hline Suri & " & $\prime \prime$ & , & " \\
\hline Kamarang-3 & " & " & $"$ & $"$ \\
\hline Amey-3 & " & " & , & " \\
\hline Badoi & " & " & " & " \\
\hline $\begin{array}{l}\text { Turki } \\
\text { Kangbui }\end{array}$ & Kaptai & " & ", & ", \\
\hline Kongcho & $"$ & $"$ & " & $"$ \\
\hline Bidi & $"$ & $"$ & , & " \\
\hline Kobrok & $"$ & $"$ & " & " \\
\hline Mongkhoi & ", & ", & , & " \\
\hline
\end{tabular}

rice (Oryza sativa L.)' issued by GRSD, BRRI (2018) (Table 2). Again, specifically ten plants from each entry were randomly selected for recording data on 15 quantitative traits namely, flag leaf length, flag leaf width, leaf area index, culm diameter, plant height, effective tiller number, panicle length, days to flowering, days to maturity, filled grains per panicle, grain length, grain breadth, length-breadth ratio, 1000 grain weight (TGW) and yield per hill. Genetic diversity was worked out by the principal component analysis (Rao, 1964) and Mahalanobis' generalized distance $\left(\mathrm{D}^{2}\right)$ analysis (Rao, 1952). Intra and inter cluster distances were calculated by the methods of Singh and
Chaudhury (1985). Under multivariate analysis principal component analysis (PCA), principal coordinate analysis (PCoA), cluster analysis (CA) and canonical vector analysis (CVA) were done by using GENSTAT 5.5 programme.

\section{RESULTS AND DISCUSSION}

Collection and characterization of existing germplasm is not only important for utilizing the appropriate attribute based donors in breeding programmes, but is also essential in the present era for protecting the unique rice. Using advanced biometric techniques such as 
Table 2. Classification of Jhum rice landraces based on 23 qualitative characters.

\begin{tabular}{|c|c|c|c|c|}
\hline Character & Classification & $\begin{array}{c}\text { Total } \\
\text { variety }\end{array}$ & Landraces (Serial number in Table 1) & Frequency $\%$ \\
\hline \multirow{3}{*}{$\begin{array}{l}\text { Blade } \\
\text { pubescence }\end{array}$} & 01. Glabrous & 01 & 9 & 3.33 \\
\hline & 02. Intermediate & 28 & $\begin{array}{l}1,3,4,5,6,7,8,10,11,12,13,14,15,15,16,17,18,19,20,21,22,23,24 \\
25,26,27,28,29,30\end{array}$ & 93.34 \\
\hline & 03. Pubescent & 01 & 2 & 3.33 \\
\hline \multirow{3}{*}{ Blade colour } & 01. Pale green & 01 & 22 & 3.33 \\
\hline & 02. Green & 28 & $\begin{array}{l}1,2,3,4,5,7,8,9,10,11,12,13,14,15,16,17,18,19,20,21,23,24,25,2 \\
6,27,28,29,30\end{array}$ & 93.34 \\
\hline & 05. Purple margins & 01 & 6 & 3.33 \\
\hline \multirow{2}{*}{$\begin{array}{l}\text { Leaf sheath: } \\
\text { anthocyanin } \\
\text { colour }\end{array}$} & 01. Absent & 28 & $\begin{array}{l}1,2,3,4,5,7,8,9,10,11,13,14,15,16,17,18,19,20,21,22,23,24,25,2 \\
6,27,28,29,30\end{array}$ & 93.33 \\
\hline & 09. Present & 02 & 6,12 & 6.67 \\
\hline \multirow{3}{*}{$\begin{array}{l}\text { Basal leaf sheath } \\
\text { colour }\end{array}$} & 01. Green & 28 & $\begin{array}{l}1,2,3,4,5,7,8,9,10,11,13,14,15,16,17,18,19,20,21,22,23,24,25,2 \\
6,27,28,29,30\end{array}$ & 93.34 \\
\hline & 02. Purple lines & 01 & 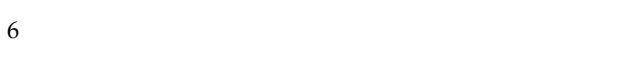 & 3.33 \\
\hline & 03. Light purple & 01 & 12 & 3.33 \\
\hline \multirow{4}{*}{ Flag leaf angle } & 01. $\operatorname{Erect}\left(<30^{\circ}\right)$ & 10 & $1,2,3,8,14,16,17,18,24,27$ & 33.33 \\
\hline & 03. Semi erect $\left(<30-45^{0}\right)$ & 06 & $7,11,19,23,26,30$ & 20 \\
\hline & 05. Horizontal $\left(<46-90^{\circ}\right)$ & 09 & $6,9,15,20,21,22,25,26,28$ & 30 \\
\hline & 07. Descending $\left(>90^{\circ}\right)$ & 05 & $4,5,12,13,29$ & 16.67 \\
\hline \multirow{2}{*}{ Ligule colour } & 01. White & 29 & $\begin{array}{l}1,2,3,4,5,7,8,9,10,11,12,13,14,15,16,17,18,19,20,21,22,23,24,2 \\
5,26,27,28,29,30\end{array}$ & 96.67 \\
\hline & 03. Purple & 01 & 6 & 3.33 \\
\hline Ligule shape & 02. 2- cleft & 30 & $\begin{array}{l}1,2,3,4,5,6,7,8,9,10,11,12,13,14,15,16,17,18,19,20,21,22,23,24 \\
25,26,27,28,29,30\end{array}$ & 100 \\
\hline \multirow[t]{2}{*}{ Collar colour } & 01. Pale green & 29 & $\begin{array}{l}1,2,3,4,5,7,8,10,11,12,13,14,15,16,17,18,19,20,21,22,23,24,25 \\
26,27,28,29,30\end{array}$ & 96.67 \\
\hline & 02. Green & 01 & 9 & 3.33 \\
\hline Auricle colour & 01. Pale green & 30 & $\begin{array}{l}1,2,3,4,5,6,7,8,9,10,11,12,13,14,15,16,17,18,19,20,21,22,23,24, \\
25,26,27,28,29,30\end{array}$ & 100 \\
\hline \multirow{2}{*}{$\begin{array}{l}\text { Culm } \\
\text { anthocyanin } \\
\text { colour }\end{array}$} & 01. Absent & 27 & $\begin{array}{l}1,2,3,4,5,7,8,9,11,12,13,14,16,17,18,19,20,21,22,23,24,25,26,2 \\
7,28,29,30\end{array}$ & 90 \\
\hline & 09. Present & 03 & $6,10,15$ & 10 \\
\hline \multirow{3}{*}{ Culm angel } & 01. $\operatorname{Erect}\left(<30^{\circ}\right)$ & 07 & $4,6,12,14,17,24,27$ & 23.33 \\
\hline & 03. Intermediate & 13 & $1,3,5,7,9,13,16,20,21,23,25,26,30$ & 43.33 \\
\hline & 05. Open & 10 & $2,8,10,11,15,18,19,22,28,29$ & 33.33 \\
\hline \multirow{4}{*}{ Internode colour } & 01. Green & 22 & $1,3,5,7,8,9,13,14,16,17,19,20,21,22,23,24,25,26,27,28,29,30$ & 73.33 \\
\hline & 02. Light gold & 05 & $2,4,11,12,18$ & 16.67 \\
\hline & 03. Purple lines & 03 & $6,10,15$ & 10 \\
\hline & 01. Strong & 18 & $1,2,3,6,7,8,10,12,13,14,15,17,20,21,24,25,27,28$ & 60 \\
\hline \multirow[t]{2}{*}{ Culm strength } & 03. Moderately strong & 11 & $5,9,11,16,18,19,22,23,26,29,30$ & 36.67 \\
\hline & 05. Intermediate & 01 & 4 & 3.33 \\
\hline \multirow{3}{*}{ Panicle type } & 01. Compact & 01 & 11 & 3.33 \\
\hline & 05. Intermediate & 06 & $4,6,15,26,29,30$ & 20 \\
\hline & 09. Open & 23 & $1,2,3,5,7,8,9,10,12,13,14,16,17,18,19,20,21,22,23,24,25,27,28$ & 76.67 \\
\hline \multirow{3}{*}{$\begin{array}{l}\text { Panicle } \\
\text { exsertion }\end{array}$} & 01. Well exerted & 13 & $1,2,3,4,5,6,7,9,14,16,18,19,21$ & 43.33 \\
\hline & 03. Moderately well exerted & 09 & $8,12,15,17,20,23,24,26,28$ & 30 \\
\hline & 05. Just exerted & 08 & $10,11,13,22,25,27,29,30$ & 26.67 \\
\hline
\end{tabular}


Table 2. Contined.

\begin{tabular}{|c|c|c|c|c|}
\hline Character & Classification & $\begin{array}{c}\text { Total } \\
\text { variety }\end{array}$ & Landraces (Serial number in Table 1) & Frequency $\%$ \\
\hline \multirow{2}{*}{$\begin{array}{l}\text { Spikelet: awns } \\
\text { in the spikelet }\end{array}$} & 01. Absent & 28 & $\begin{array}{l}1,2,3,4,5,6,7,8,9,10,11,12,13,14,15,16,18,19,20,21,23,24,25,2 \\
6,27,28,29,30\end{array}$ & 93.33 \\
\hline & 09. present & 02 & 17,22 & 6.67 \\
\hline \multirow{2}{*}{$\begin{array}{l}\text { Distribution of } \\
\text { awning } \\
\text { Awn colour }\end{array}$} & 01. Tip only & 02 & 17,22 & 6.67 \\
\hline & 01. Straw & 02 & 17,22 & 6.67 \\
\hline \multirow{3}{*}{$\begin{array}{l}\text { Apiculus } \\
\text { colour }\end{array}$} & 02. Straw & 17 & $3,10,11,13,14,16,17,19,20,21,22,23,24,26,28,29,30$ & 56.67 \\
\hline & 05. Red apex & 04 & $1,15,25,27$ & 13.33 \\
\hline & 06. Purple & 09 & $2,4,5,6,7,8,9,12,18$ & 30 \\
\hline \multirow{2}{*}{ Stigma colour } & 01. White & 26 & $\begin{array}{l}1,2,3,4,8,9,10,11,12,13,14,15,16,17,18,19,20,21,22,23,24,25, \\
26,28,29,30\end{array}$ & 86.67 \\
\hline & 05. Purple & 04 & $5,6,7,27$ & 13.33 \\
\hline \multirow{5}{*}{$\begin{array}{l}\text { Lemma and } \\
\text { palea colour }\end{array}$} & 0. Straw & 25 & $\begin{array}{l}1,2,3,5,8,10,11,12,13,14,15,16,17,18,19,20,21,22,23,24,25,2 \\
6,27,28,30\end{array}$ & 83.33 \\
\hline & 01. Gold & 01 & 29 & 3.33 \\
\hline & 03. Brown furrows on straw & 01 & 6 & 3.33 \\
\hline & 05. Reddish to light purple & 02 & 4,9 & 6.67 \\
\hline & 07. Purple furrows on straw & 01 & 7 & 3.33 \\
\hline \multirow{3}{*}{$\begin{array}{l}\text { Seed coat } \\
\text { (bran) colour }\end{array}$} & 01. White & 26 & $\begin{array}{l}1,2,3,4,7,8,9,10,11,12,13,15,17,18,19,20,21,22,23,24,25,26,2 \\
7,28,29,30\end{array}$ & 86.67 \\
\hline & 05. Red & 03 & $5,14,16$ & 10 \\
\hline & 07. Purple & 01 & 6 & 3.33 \\
\hline \multirow{2}{*}{$\begin{array}{l}\text { Leaf } \\
\text { senescence }\end{array}$} & 01.Late and slow & 01 & 9 & 3.33 \\
\hline & 05. Intermediate & 29 & $\begin{array}{l}1,2,3,4,5,6,7,8,10,11,12,13,14,15,16,17,18,19,20,21,22,23,24,2 \\
5,25,26,27,28,29,30\end{array}$ & 96.67 \\
\hline
\end{tabular}

multivariate analysis based on Mahalanobis $\mathrm{D}^{2}$ statistic (Mahalanobis, 1936), it has now become possible to quantify the degree of genetic divergence amongst populations and assessing the relative contribution of various desirable attributes of breeding and agronomic value to the total divergence by the clustering pattern. The grouping of genotypes into so many clusters had suggested the presence of high degree of diversity in the materials evaluated.

\section{Qualitative traits characterization}

Among the investigated 38 agro-morphological characters, 23 characters were qualitative. Qualitative characters are important in respect to the identification and the characterization of landraces of rice varieties because it was observed that these characters are less influenced by the various environmental conditions. Polymorphism was found in 21 of the 23 qualitative traits under studied; the non-polymorphic traits were ligule shape and auricle colour (Table 2). The detailed phenotypic characterizations of Jhum rice landraces for 23 qualitative agro-morphological characters are as follows:

\section{Leaf traits}

Jhum rice landraces were characterized for leaf traits at late vegetative and flowering stages. Most of the characterized Jhum rice (28) landraces (93.34\%) exhibited intermediate leaf blade while the rest of the landraces showed pubescent $(3.33 \%)$ and glabrous $(3.33 \%)$ type. Similarly, it was observed in the present study that 28 landraces had green $(93.34 \%)$ color leaf blade, while one had pale green $(3.33 \%)$ and one had purple margin $(3.33 \%)$ colour leaf blade. However, the anthocyanin colouration of leaf sheath was present only on two landraces $(6.67 \%)$, while the rest (28) had no coloration $(93.33 \%)$ of anthocyanin. The maximum number of landraces $(33.33 \%)$ had erect $\left(<30^{\circ}\right)$ type of flag leaf blade, while $(20 \%)$ of each had semi-erect $\left(<30-45^{\circ}\right)$ and $(30 \%)$ horizontal $(<46-$ $\left.90^{\circ}\right)$ and only $16.67 \%$ had descending $\left(>90^{\circ}\right)$ type of flag leaf.

\section{Ligule traits}

Ligule colour of 29 landraces was observed white $(96.67 \%)$ type colour while the remaining only one lonkapara binni landrace showed 
purple colour. There was no divergence found in ligule shape for the studied landraces. All the landraces were observed 2-clefted. Again, most of the landraces (29) showed pale green $(96.67 \%)$ collar colour while the remaining just one landrace namely bandornok binni was observed having green collar colour (3.33\%).

\section{Culm traits}

The qualitative characters showing higher variability were culm angle $(23.33 \%$ erect, $43.33 \%$ intermediate and $33.33 \%$ open), internode colour $(73.33 \%$ green, $16.67 \%$ light gold and $10 \%$ purple line), culm strength (60 $\%$ strong, $36.67 \%$ moderately strong and $3.33 \%$ intermediate).

\section{Panicle traits}

On the basis of attitude of panicle, 23 landraces had open type $(76.67 \%)$ of panicle among the 30 landraces. Six landraces had intermediate type $(20 \%)$ of panicle and rest of the one landrace namely Lokkhi binni had compact type (3.33\%) of panicle. Among the 30 landraces of Jhum had well exerted $(43.33 \%)$, moderately well exerted $(30 \%)$ and just exerted $(26.67 \%)$ on the basis of panicle exersion.

\section{Grain traits}

Based on awns in the spikelet, most of the 28 landraces awns were absent (93.33\%) and two landraces (Pattiki and Kamarang-3) had present awns $(6.67 \%)$. Again, two landraces awns were distributed on the tip only and colour was straw. The spikelets showed straw $(56.67 \%)$, red apex $(13.3 \%)$ and purple $(30 \%)$ colour apiculus. On the basis of stigma colour, white $(86.67 \%)$ and purple $(13.33 \%)$ colour was observed in 28 and two landraces, respectively. Among the 30 landraces, various colours were observed in husk (lemma and palea) of different landraces. Straw colour $(83.33 \%)$ lemma and palea were recorded in 25 landraces, gold $(3.33 \%)$ in one, brown furrows on straw $(3.33 \%)$ in lonkapara binni and reddish to light purple in two landraces namely Horinbinni and Bandornok binni. Also, one landraces Turni had purple furrow on straw (3.33\%). Around, 26 landraces showed white $(86.67 \%)$ seed coat colour, while three (Bairi, Koborok-2 and Chorui) and one (Lonkapara binni) landrace had red $(10 \%)$ and purple $(3.33 \%)$ seed coat colour, respectively. Maximum number of landraces 29 had intermediate type $(96.67 \%)$ and one landrace had late and slow type (3.33\%) of leaf senescence at the time of maturity among the 30 Jhum rice landraces.

The present study exhibits high variability in most of the observed qualitative traits of Jhum rice landraces. Similar findings were reported by Akter et al. (2017), Mau et al. (2017), Ahmed et al. (2016b), Nascimento et al. (2011) and Moukoumbi et al. (2011). However, Ahmed et al. (2015a) characterized 21 genotypes of similar or duplicate named Kartiksail rice germplasm of Bangladesh and showed no anthocyanin colour in auricles, weak and medium intensity of anthocyanin colour in basal leaf sheath (each $5 \%)$, green leaf blade colour $(47 \%)$ and white colour of stigma (90\%). Parikh et al. (2012) also observed majority of the genotypes to possess green basal leaf sheath colour $(84.5 \%)$, green leaf blade colour $(86.8 \%)$, white ligule colour $(94.7 \%)$, light green auricle colour $(97.3 \%)$, semi erect plant habit $(44.7 \%)$, straw apiculus colour $(53.9 \%)$ and awnless $(72.3 \%)$ in 71 aromatic rice germplasm.

\section{Quantitative traits characterization}

Table 3 presents Eigen values (latent roots) and percentage of total variation accounted for them obtained from principle component analysis. The result exposed that the first five components in the PCA with Eigen values $>1.0$, contributed $81.14 \%$ of the total variations among the genotypes for 15 morphological characters. These results are in agreement with the findings of Ahmed et al. (2015b). Fig. 1 presents a two dimension chart $\left(Z_{1}-Z_{2}\right)$ of the landraces based on principal axes. As per the scattered diagram, the Jhum rice landraces were apparently distributed into five clusters.

The clustering pattern was determined by the principal component analysis (PCA), which represents composition of different clusters with the landraces (Table 4). Maximum 8 landraces 
Table 3. Latent roots (eigen values) and their variation in 15 quantitative characters in 36 Jhum rice landraces.

\begin{tabular}{llccc}
\hline Character & Principal component axes & Latent root & Variation (\%) & Cumulative \% of variation \\
\hline Flag leaf length (cm) & PC 1 & 3.890 & 25.94 & 25.94 \\
Flag leaf width (cm) & PC 2 & 3.179 & 21.20 & 47.14 \\
Leaf area index (cm $\left.{ }^{2}\right)$ & PC 3 & 2.350 & 15.67 & 62.81 \\
Culm diameter (mm) & PC 4 & 1.497 & 9.98 & 72.79 \\
Plant height (cm) & PC 5 & 1.253 & 8.35 & 81.14 \\
Effective tiller number & PC 6 & 0.883 & 5.89 & 87.03 \\
Panicle length (cm) & PC 7 & 0.812 & 5.42 & 92.45 \\
Days to flowering & PC 8 & 0.380 & 2.54 & 94.99 \\
Days to maturity & PC 9 & 0.271 & 1.81 & 96.8 \\
Filled grains per panicle & PC 10 & 0.210 & 1.41 & 98.21 \\
Grain length (mm) & PC 11 & 0.156 & 1.04 & 99.25 \\
Grain breadth (mm) & PC 12 & 0.101 & 0.67 & 99.92 \\
Length-breath ratio & PC 13 & 0.006 & 0.04 & 99.96 \\
1000 grain weight (g) & PC 14 & 0.004 & 0.03 & 99.99 \\
Yield/hill (g) & PC15 & 0.001 & 0.01 & 100 \\
\hline
\end{tabular}

Table 4. Distribution of 30 Jhum rice landraces into five clusters.

\begin{tabular}{llll}
\hline \multicolumn{1}{c}{ Cluster } & No. of landraces & \% total & \multicolumn{1}{c}{ Landrace } \\
\hline I & 6 & 20.00 & Amey-1, Horinbinni, Bandornok binni, Kamarang-1, Suri, Kobrok \\
II & 4 & 13.33 & Lonkapara binni, Gonda, Amey-2, Kamarang-2 \\
III & 6 & 20.00 & Koborok-2, Galong, Chorui, Kamarang-3, Bidi, Mongkhoi \\
IV & 8 & 26.67 & Kobrok-1, Bairi, Turni, Vanguri valo, Kangbui, Pattiki, Guri, Turki \\
V & 6 & 20.00 & Vanguri Jhum, Lokkhi binni, Amey-3, Badoi, Kangbui, Kongcho \\
\hline
\end{tabular}

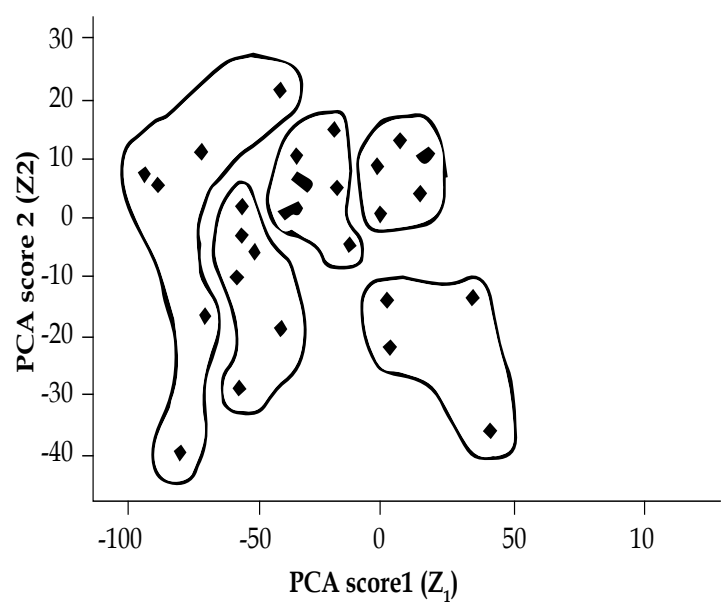

Fig. 1. Scatter diagram of 30 Jhum rice landraces based on their principal component scores superimposed with clustering. were grouped into the cluster IV followed by six in cluster I, III and V. The cluster II contained the lowest (4) number of landraces. Siddique et al. (2011) found five clusters from 38 rice landraces of hilly areas of Bangladesh. Similarly, Khatun et al. (2015) studied five clusters from 43 upland rice genotypes. Again, Roy et al. (2004) found five clusters from 35 Aman rice cultivars for 10 traits during Kharif season.

Table 5 shows results of five higher and five lower inter genotypic distances estimated from distant matrix of Principal Coordinate Analysis. The highest inter genotypic distance was 1.22 observed between Koborok-2 and Chorui followed by the distance of 1.20 observed between Galong and Bidi. The lowest distance was calculated (0.37) between Bairi 
Table 5. Five higher and five lower inter genotypic distance among the 30 Jhum rice landraces.

\begin{tabular}{ll}
\hline Genotypic combination & Distance \\
\hline A. Five higher inter genotypic distance & \\
Koborok 2- Chorui & 1.22 \\
Galong- Bidi & 1.20 \\
Kamarang 1-Suri & 1.17 \\
Lonkapara binni- Amey 2 & 1.13 \\
Bandornok binni- Suri & 1.11 \\
B. Five lower inter genotypic distance & \\
Bairi - Kangbui & 0.37 \\
Vanguri valo- Turki & 0.39 \\
Horinbinni- Bandornok binni & 0.43 \\
Bairi- Vanguri valo & 0.47 \\
Bandornok binni- Kamarang 1 & 0.50 \\
\hline
\end{tabular}

and Kangbui followed by the distance of 0.39 observed between Vanguri valo and Turki. Buu and Tuan (1989) and Joshi and Dhawan (1966) reported that genetic diversity is very much important factor for any hybridization programme aiming at genetic improvement of yield especially in self-pollinated crops like rice. Again, Bhatt (1970) inferred that Mahalanobis's $\mathrm{D}^{2}$ statistic is a powerful tool for choosing diverse parents for hybridization.

Table 6 presents the average intra and inter-cluster distances $\left(\mathrm{D}^{2}\right)$. The intra-cluster distance was maximum in cluster III (1.62) containing six genotypes followed by cluster II (0.85) with four genotypes and minimum in cluster I (0.57) having six genotypes and the cluster IV showed the second lowest intracluster distance $(0.68)$ having the highest (8) number of genotypes. Such results indicated that the landraces of cluster III were the most diverse and those of cluster I was most similar or less diverse.
Regarding the inter-cluster distance, the maximum genetic distance was observed between the clusters II and V (23.44) followed by clusters I and V (17.56), while the minimum was observed between the clusters III and IV (7.29) followed by cluster I and II (7.48). The maximum value of inter-cluster distance indicated that the genotypes belonging to cluster $\mathrm{V}$ was far diverged from those of cluster II. The minimum inter-cluster divergence was observed between cluster IV and III (7.29) indicating that the genotypes of these clusters were genetically closed. However, genotypes within the other pair of clusters indicated that they were less diverged. The inter-cluster distances in all the clusters were higher than the intra-cluster distances suggesting wider genetic diversity among the genotype of different groups. The results were in agreement with Islam et al. (2016), Akter et al. (2016), Ahmed et al. (2015b), Islam et al. (2014) and Sohrabi et al. (2012).

Table 7 presents the cluster-mean values for all the 15 quantitative characters. The data revealed that different clusters exhibited the highest and lowest mean values of individual characters and none of the single cluster showed the highest or lowest mean values of all the characters. However, the highest cluster means for yield/hill, days to maturity and effective tiller number were obtained from cluster III. The highest flag leaf length, leaf area index, filled grains per panicle were found in cluster $V$ while the lowest culm diameter, short duration, low yielding genotypes were clubbed into cluster II. Dwarf stature and lower flag leaf length were recorded into cluster I whereas the highest plant height and panicle length were obtained from cluster IV. Maximum good characters were accumulated in cluster III and as a result

Table 6. Intra (bold) and inter-cluster distances $\left(D^{2}\right)$ for 30 Jhum rice landraces.

\begin{tabular}{lccccc}
\hline Cluster & I & II & III & IV & V \\
\hline I & $\mathbf{0 . 5 7}$ & 7.48 & 12.20 & 8.94 & 17.56 \\
II & & 0.85 & 17.10 & 11.54 & 23.44 \\
III & & $\mathbf{1 . 6 2}$ & 7.29 & 7.51 \\
IV & & & 0.68 & 13.24 \\
V & & & & $\mathbf{0 . 7 7}$ \\
\hline
\end{tabular}


Table 7. Cluster means for $\mathbf{1 5}$ quantitative characters in $\mathbf{3 0}$ Jhum rice landraces.

\begin{tabular}{lccccc}
\hline Character & I & II & III & IV & V \\
\hline Flag leaf length $(\mathrm{cm})$ & 38.47 & 38.96 & 40.27 & 45.20 & 46.17 \\
Flag leaf width $(\mathrm{cm})$ & 1.75 & 1.57 & 1.53 & 1.56 & 1.61 \\
Leaf area index $\left(\mathrm{cm}^{2}\right)$ & 50.42 & 46.20 & 46.39 & 52.65 & 55.56 \\
Culm diameter $(\mathrm{mm})$ & 4.69 & 4.42 & 5.05 & 4.47 & 5.22 \\
Plant height $(\mathrm{cm})$ & 109.43 & 113.68 & 118.20 & 131.31 & 122.87 \\
Effective tiller number & 7.00 & 7.00 & 9.00 & 8.00 & 6.00 \\
Panicle length (cm) & 26.83 & 28.16 & 28.63 & 29.60 & 28.73 \\
Days to flowering & 91 & 86 & 94 & 89 & 91 \\
Days to maturity & 119 & 114 & 120 & 116 & 118 \\
Filled grains per panicle & 89.00 & 62.00 & 134.00 & 106.00 & 160.00 \\
Grain length (mm) & 9.64 & 9.69 & 8.22 & 7.79 & 8.48 \\
Grain breadth (mm) & 3.16 & 3.24 & 2.87 & 3.05 & 3.15 \\
Length-breath ratio & 3.10 & 3.04 & 2.96 & 2.58 & 2.78 \\
TGW (g) & 28.42 & 28.00 & 19.15 & 22.13 & 23.13 \\
Yield/hill (g) & 5.12 & 4.41 & 6.82 & 5.26 & 4.83 \\
\hline
\end{tabular}

higher yield (6.82 g/hill) was also obtained in this cluster. But it was interesting that in most of the cases cluster $V$ could produced the highest $\mathrm{D}^{2}$ values with all other clusters except cluster III. So they can be used in hybridization programme to produce higher yielding genotypes. Therefore, the landraces under cluster II, cluster III and cluster $\mathrm{V}$ might be selected for future breeding programme. Siddique et al. $(2013,2016)$ and Sohrabi et al. (2012) earlier reported similar trend of conclusions on rice using Mahalanobis' $\mathrm{D}^{2}$ statistics.

Table 8 presents contributions of the characters towards divergence. The canonical variate analysis revealed that the vectors (Vector I and II) for culm diameter, days to flowering, days to maturity and length-breath ratio were positive. Such results indicated that these four characters contributed maximum towards divergence. It is interesting that the greater divergence in the present materials due to these four characters will offer a good scope for improvement of yield through rational selection of parents for producing heterotic rice hybrids. Similar findings also reported by Islam et al. (2009) for local rice germplasm.
Table 8. Relative contributions of the fifteen characters to the total divergence in Jhum rice landraces.

\begin{tabular}{lcc}
\hline Character & Vector 1 & Vector 2 \\
\hline Flag leaf length $(\mathrm{cm})$ & 0.300 & -0.068 \\
Flag leaf width $(\mathrm{cm})$ & 0.125 & -0.017 \\
Leaf area index $\left(\mathrm{cm}^{2}\right)$ & 0.311 & -0.057 \\
Culm diameter $(\mathrm{mm})$ & 0.294 & 0.177 \\
Plant height $(\mathrm{cm})$ & 0.272 & -0.250 \\
Effective tiller number & -0.103 & -0.219 \\
Panicle length $(\mathrm{cm})$ & 0.292 & -0.190 \\
Days to flowering & 0.407 & 0.215 \\
Days to maturity & 0.396 & 0.218 \\
Filled grains per panicle & 0.164 & -0.225 \\
Grain length (mm) & -0.068 & 0.513 \\
Grain breadth $(\mathrm{mm})$ & -0.275 & -0.151 \\
Length-breath ratio & 0.133 & 0.450 \\
TGW (g) & -0.293 & 0.318 \\
Yield/hill (g) & 0.0735 & -0.280 \\
\hline
\end{tabular}

\section{CONCLUSIONS}

Based on the results of the current study, we made some conclusions as follows: (i) Jhum rice landraces from Rangamati district showed good diversity in both qualitative and quantitative agro-morphological traits. (ii) Cluster analysis using quantitative traits of 
30 landraces grouped them into five clusters. (iii) Observed variances in qualitative data were mostly explained by blade pubescence, anthocyanin colour of leaf sheath, apiculus colour, stigma colour, lemma-palea colour, grain tip colour and awning while considering results from genetic distance, the landraces Koborok -2, Chorui, Galong, Bidi, Kamarang-1 and Suri could be selected as parents for further breeding programme. Besides, selection of parents from the clusters II and V may be useful for breeding to obtain desirable transgressive segregants. Moreover, characterizations of the identified landraces need to be done using SSR markers for protection from biopiracy.

\section{ACKNOWLEDGEMENTS}

The authors are grateful to the project on 'Collection, characterization and promotion of rice, chilli, cucumber and melon in Bangladesh' supported by AFACI (Asian Food and Agriculture Cooperation Initiative) for providing funds for this research.

\section{REFERENCES}

Ahmed, M S, S Parveen, M K Bashar and A K M Shamsuddin. 2015b. Genetic divergence of Balam rice (Oryza sativa L.) germplasm of Bangladesh. Bangladesh Rice J. 19(1): 9-14.

Ahmed, M S, M Khalequzzaman, M K Bashar and A K M Shamsuddin. 2015a. Qualitative agro-morphological character diversity of similar or duplicate named rice (Oryza sativa L.) germplasm of Bangladesh. Journal of biodiversity and environmental science. 7 (4): 51-61.

Ahmed, M S, M K Bashar and A K M Shamsuddin. 2016b. Study of qualitative characters of Balam Rice (Oryza sativa L.) landraces of Bangladesh. Rice Genomics and Genetics. 7 (1): 1-8.

Ahmed, M S, M Khalequzzaman, M K Bashar and A K M Shamsuddin. 2016a. Agro-morphological, physicochemical and molecular characterization of rice germplasm with similar names of Bangladesh. Rice Sci. 23 (4): 211-218.

Akter, N, M Z Islam, A Bhuiya, M A Siddique and M Khalequzzaman. 2017. Distinctness of 45 irrigated rice (Oryza sativa L.) landraces of Bangladesh through agro-morphological traits. Eco-friendly Agril. J. 10(10): 100-107.

Akter, N, M Z Islam, M A Siddique, T Chakrabarty, M Khalequzzaman and M A Z Chowdhury. 2016. Genetic diversity of Boro rice (Oryza sativa L.) landraces in Bangladesh. Bangladesh J. Pl. Breed. Genet. 29 (2): 33-40.

BBS. 2015. Year book of agricultural statistics 2015. $27^{\text {th }}$ ed. Bangladesh Bureau of Statistics, Statistics and Informatics Division, Ministry of Planning, Gov. of the People's Republic of Bangladesh. www.bbs.gov. bd.

Bedoya, C A, S Dreisigacker, S Hearne, J Franco, C Mir and B M Prasanna. 2017. Genetic diversity and population structure of native maize populations in Latin America and the Caribbean. PLoS ONE. 12(4): e0173488. https://doi.org/10.1371/journal. pone. 0173488 .

Bhatt, G M. 1970. Multivariate analysis approach to selection of parents of hybridization aiming at yield improvement in self-pollinated crops. Aust. J. Agric. Res. 21: 1-7.

BRRI (Bangladesh Rice Research Institute). 2016. Annual Report 2014-15. Gazipur 1701, Bangladesh.

Buu, B C and T M Tuan. 1989. Genetic diversity in rice (Oryza sativa L.). Int. Rice Res. Newslett. 14: 6.

GRSD, BRRI. 2018. Descriptors for cultivated rice (Oryza sativa L). Genetic Resources and Seed Division, Bangladesh Rice Research Institute, Gazipur-1701, Bangladesh.

HIES. 2010. Household Income and Expenditure Survey, Bangladesh Bureau of Statistics, Ministry of Planning, Government of the People's Republic of Bangladesh, Dhaka.

Islam , M Z, K Akter, E S M H Rashid, M Khalequzzaman and M K Bashar. 2009. Genetic diversity of local irrigated rice (Oryza sativa L.) Bangladesh J. Pl. Breed. Genet. 22(2): 51-56.

Islam, M Z, M A Siddique, E S M H Rashid, M S Ahmed and M Khalequzzaman. 2014. Genetic Diversity in Sadajira Rice (Oryza sativa L.) Germplasm. The Agriculturists. 12(1): 26-32.

Islam, M Z, M Khalequzzaman, M K Bashar, N A Ivy, M M Haque and M A K Mian. 2016. Variability assessment of aromatic and fine rice germplasm in Bangladesh based on quantitative traits. The Sci. World J. http:/ / dx.doi.org/10.1155/2016/2796720.

Joshi, A B and N L Dhawan. 1966. Genetic improvement of yield with special reference to self-fertilizing crops. Indian J. Genet. Pl. Breed. 26A: 101-113.

Khatun, M T, M M Hanafi, M R Yusop, M Y Wong, F M Salleh and J Ferdous. 2015. Genetic variation, 
heritability and diversity analysis of upland rice (Oryza sativa L.) genotypes based on quantitative traits. Bio Med Research International, Article ID 290861.

Khodadadi, M, M H Fotokian and M Miransari. 2014. Genetic diversity of wheat (Triticum aestivum L.) genotypes based on cluster and principal component analyses for breeding strategies. AJCS, 5(1): 17-24.

Mahalanobis, P C. 1936. On the generalized distance in Statistics. Proc. Natl. Inst. Sci., India 2: 49-55.

Malek, M A, M Y Rafii, M S S Afroz, U K Nath, and M M A Mondal. 2014. Morphological characterization and assessment of genetic variability, character association, and divergence in Soybean mutants. The Sci. World J.1-12, http://dx.doi. org/10.1155/2014/968796.

Mau, Y S, J E R Markus, S S Oematan, A S S Ndiwa, D D Handoko, A Nasution and K Makbul. 2017. Genetic diversity of red and black upland rice accessions from East Nusa Tenggara, Indonesia as revealed by agro morphological characters. Biodiversitas. 18 (1): 197-211.

Moukoumbi, Y D, M Sie, R Vodouhe, B N Dri, B Toulou, S A Ogunbayo and A Ahanchede. 2011. Assessing phenotypic diversity of interspecific rice varieties using agro-morphological characterization. J. Plant Breed. and Crop Sci., 3(5): 74-86.

Nascimento, W F, E F Silva and E A Veasey. 2011. Agromorphological characterization of upland rice accessions. Sci. Agriculture (Piracicaba, Braz.). 68(6): 652-60.
Parikh, M, N K Motiramani, N K Rastogi and B Sharma. 2012. Agro-morphological characterization and assessment of variability in aromatic rice germplasm. Bangladesh J. Agril. Res. 37(1): 1-8.

Rao, C R. 1952. Advance Statistical Methods in Biometrical Research. New York, USA: John Willey and Sons Inc: 390.

Rao, C R. 1964. The use and interception of principal component analysis in applied research. Sankhya Ser A, 22: 317-318.

Roy, S K, A Kundu, S P Chand and B K Senapati. 2004. Diversity of panicle characters in Aman rice (Oryza sativa L). Environ. Ecol. 22(Spl-3): 500-503.

Siddique , M A, M Khalequzzaman, M Z Islam, M H K Baktiar and M S Ahmed. 2016. Genetic diversity assessment of quantitative traits in landraces of Aus rice. Bangladesh J. Pl. Breed. Genet. 29(2): 17-24.

Siddique, M A, M Z Islam, M Khalequzzaman and M $S$ Ahmed. 2011. Genetic diversity in rice (Oryza sativa L.) landraces of hilly areas in Bangladesh. Bangladesh J. Pl. Breed. Genet. 24(2): 25-30.

Siddique, M A, M Khalequzzaman, M Z Islam, M S Ahmed and E S M H Rashid. 2013. Genetic diversity in local Boro rice (Oryza Sativa L.) genotypes of Bangladesh. Bangladesh J. Pl. Breed.Genet. 26(1): 19-24.

Singh, R K and B D Chaudhury. 1985. Biometrical methods in quantitative genetic analysis. Kalayoni publishers. New Delhi. 318 p.

Sohrabi, M, M Y Rafii, M M Hanafi, A S N Akmar and M A Latif. 2012. Genetic diversity of upland rice germplasm in Malaysia based on quantitative traits. The Sci. World. J., 416291: 1-9. 
